\title{
JUKMAS
}

Jurnal Untuk Masyarakat Sehat (JUKMAS)

e-ISSN : 2715-7687

Vol. 4, No. 2 Oktober 2020

P-ISSN : 2715-8748

\section{Hubungan Kinerja Kader Posyandu Balita dengan Kepuasan Pelayanan Posyandu Balita di RW 012 Kelurahan Kapuk Jakarta Utara Tahun 2020}

\author{
Petrus Yohanes Lui Lelaona, Sri Siswani \\ Universitas Respati Indonesia \\ Email : siswanisri@yahoo.co.id
}

\begin{abstract}
Abstrak
Posyandu adalah salah satu bentuk Upaya Kesehatan Bersumber Daya Masyarakat (UKBM) yang dikelola dan diselenggarakan dari, oleh, untuk dan bersama masyarakat dalam penyelenggaraan pembangunan kesehatan guna mempercepat penurunan angka kematian ibu (AKI) dan angka kematian bayi (AKB). Posyandu Balita di RW 012 Kelurahan kapuk terdiri atas 6 posyandu yaitu posyandu melati $1 \mathrm{~s} / \mathrm{d} 6$. Hasil survei pendahuluan, adapun jumlah balita per posyandu di RW 012 Kelurahan kapuk diantaranya posyandu melati 1 dengan jumlah balita sebanyak 350, posyandu melati 2 dengan jumlah balita sebanyak 393, posyandu melati 3 dengan jumlah balita sebanyak 278, posyandu melati 4 dengan jumlah balita sebanyak 295, posyandu melati 5 dengan jumlah balita sebanyak 125 dan posyandu melati 6 dengan jumlah balita sebanyak 120 . Tujuan penelitian untuk Mengetahui hubungan antara kinerja kader Posyandu terhadap kepuasan Pelayanan Posyandu Balita di RW 012 Kelurahan Kapuk Tahun 2020. Jenis penelitian yang digunakan adalah Analitik kuantitatif dengan menggunakan pendekatan studi Cross Sectional. Hasil penelitian didapatkan responden yang menyatakan puas lebih banyak dibandingkan tidak puas sebesar $61,4 \%$ dan responden yang menyatakan kinerja baik lebih besar dibandingkan tidak baik sebesar 72,4\%. Hasil uji statistik diperoleh ada hubungan antara kinerja kader posyandu balita terhadap kepuasan ibu pengguna posyandu balita dengan $p$ value $=0,0001$. Kesimpulan pada penelitian ini didapatkan hubungan antara kinerja kader posyandu balita dengan kepuasan ibu pengguna posyandu balita.
\end{abstract}

Kata Kunci : Kinerja, Kepuasan, dan Posyandu Balita

\section{Abstract}

Posyandu is a form of Community-Based Health Efforts (UKBM) which are managed and organized from, by, for and with the community in implementing health development in order to accelerate the reduction of maternal mortality (MMR) and infant mortality rates (IMR). Posyandu for Toddlers in RW 012 Kapuk sub-district consists of 6 posyandu, namely Posyandu Melati 1 to 6 . Preliminary survey results, as for the number of children under five per posyandu in RW 012 Kapuk sub-district including Posyandu Melati 1 with 350 children under five, Posyandu Melati 2 with the number of children under five as many as 393, Posyandu Melati 3 with 278 toddlers, Posyandu Melati 4 with 295 children under five, Posyandu Melati 5 with 125 toddlers and Posyandu Jasmine 6 with 120 under five. Toddler Posyandu services at RW 012 Kelurahan Kapuk in 2020. The type of research used is quantitative analysis using a cross sectional study approach. The results showed that respondents who stated that they were satisfied were more than those who were dissatisfied by $61.4 \%$ and respondents who stated that they had a good performance were greater than those who were not good at $72.4 \%$. The results of statistical tests showed that there was a relationship between the performance of the posyandu cadres for toddlers with the mother's satisfaction of using the

http://ejournal.urindo.ac.id/index.php/jukmas

Article History :

Submitted 01 Oktober 2020, Accepted 30 Oktober 2020, Published 310ktober 2020 
posyandu under five with $p$ value $=0.0001$. The conclusion in this study is that there is a relationship between the performance of the posyandu cadres with toddlers' mother satisfaction.

Keywords: Performance, Satisfaction, and Toddler Posyandu

\section{PENDAHULUAN}

Di Indonesia tingkat keberhasilan pembangunan pelayanan kesehatan sangat erat dengan adanya partisipasi masyarakat dan lembaga lainnya dalam dalam mensukseskan upaya kegiatan kesehatan masyarakat yang dimulai dari setiap indivisu, keluarga dan masyarakat. Pemerintah mencanangkan rencana program di bidang kesehatan yang untuk menopang program pelayanan kesehatan tradisional maupun konvensional yang kembangkan oleh masyarakat POSYANDU (Pos Pelayanan Terpadu) [1].

Menurut Profil Dinkes DKI Jakarta, adapun jumlah posyandu di DKI Jakarta pada tahun 2018 adalah sebanyak 4.427 posyandu dan sebanyak 4.245 atau sekitar 95,89\% merupakan posyandu aktif. Pada tahun 2015 jumlah posyandu aktif terdapat 2.495 posyandu aktif, tahun 2016 terdapat 4.372 posyandu aktif dan 2017 terdapat 4.384 posyandu aktif. Berdasarkan data tersebut, dapat kita lihat bahwa terdapat trend jumlah posyandu aktif dari tahun 2015-2018. Jumlah posyandu aktif di DKI Jakarta terbanyak yaitu di Jakarta Selatan dengan presentase 99,2 \% atau dengan jumlah 1.245 posyandu aktif. Sementara Jakarta timur, menempati urutan ke dua yaitu sebanyak 96,6\%. Hal tersebut dikarenakan mayoritas warga DKI Jakarta peduli dengan pengelolaan kesejahteraan masyarakat, salah satunya yaitu Posyandu. Sehingga peran serta UKM Puskesmas dalam melaksanakan program-programnya meningkat [2].

Kinerja kader posyandu sangat berpengaruh terhadap kepuasan ibu pengguna posyandu balita. Kepuasan merupakan bagian penting dan menunjang kualitas pelayanan kesehatan. Survei kepuasan adalah hal penting yang harus dilakukan sejalan dengan pengukuran kualitas pelayanan kesehatan. Seperti yang ditunjukkan oleh Pratiwi et al (2014) dalam pertiwi (2017) kepuasan adalah konsekuensi dari penilaian konsumen terhadap berbagai bagian kualitas pelayanan. Mengekspresikan kualitas administrasi harus dimulai dengan kebutuhan pembeli dan diakhiri dengan persepsi pembeli [3]. Kepuasan Ibu pengguna posyandu balita merupakan salah satu elemen penting dalam menentukan pencapaian sebuah program 
pelayanan. Ini mengisyaratkan bahwa kualitas pelayanan yang baik tidak tergantung pada pandangan organisasi itu sendiri, namun tergantung pada kesan pelanggan karena pelanggan yang merasakan atau menikmati pelayanan organisasi atau perusahaan tersebut [4].

Posyandu Balita di RW 012 Kelurahan kapuk terdiri atas 6 posyandu yaitu posyandu melati $1 \mathrm{~s} / \mathrm{d} 6$. Hasil survei pendahuluan, adapun jumlah balita per posyandu di RW 012 Kelurahan kapuk diantaranya posyandu melati 1 dengan jumlah balita sebanyak 350, posyandu melati 2 dengan jumlah balita sebanyak 393, posyandu melati 3 dengan jumlah balita sebanyak 278 , posyandu melati 4 dengan jumlah balita sebanyak 295, posyandu melati 5 dengan jumlah balita sebanyak 125 dan posyandu melati 6 dengan jumlah balita sebanyak 120 . Total balita dari ke 6 posyandu tersebut sebanyak 1.561 balita. Setiap posyandu mempunyai 6 kader jadi total kader sebanyak 36 kader.

Hasil Wawancara yang peneliti lakukan terhadap 5 reponden pada tanggal 29 April 2020, rata-rata menyatakan kinerja cukup baik, namun perlu di tingkatkan lagi dalam hal kecepatan dan ketanggapan dalam memberikan pelayanan. Ini artinya bahwa kecepatan dan ketangapan dari kader masih kurang memberikan kepuasan terhadap pengunjung. Beberapa diantaranya mengeluhkan waktu tunggu antrian pelayanan lama yang membuat anak bosan dan menangis sehinga ada yang pulang sebelum di timbang. Hal ini sejalan dengan pendapat Pohan 2007 bahwa waktu tunggu adalah salah satu dari sebelas aspek yang mempengaruhi kepuasan. Dilain pihak Penjelasan ataupun informasi yang diberikan oleh petugas juga kadang tidak sesuai harapan.

Dari hasil wawancara dengan pihak kader, mereka menyatakan bahwa sudah berusaha memberikan pelayanan yang maksimal, selalu mendahulukan yang datang dan berusahan untuk tepat waktu. Namun karena banyaknya pengunjung sehingga ada keterbatasan terutama terkait waktu dan lamanya antrian.

Wawancara lanjutan yang peneliti lakukan menggunakan kuesioner pada tanggal 17 Juni 2020 terhadap 10 orang responden terkait 5 indikator kinerja dan 5 indikator kepuasan, diperoleh bahwa untuk Variabel Kinerja, pada indikator kinerja spesifik dan measurabel terlihat hampir semua responden menyatakan sudah sesuai, namun pada 3 indikator kinerja lainnya yaitu attributable, relevant, dan timely, beberapa diantarannya menyatakan kurang sesuai. Terkait indikator kinerja Atributabel, 2 diantara responden berpendapat bahwa kader posyandu masih 
kurang membina kerjasama yang baik dengan pengunjung. Pada indikator kinerja Relevant, 2 respoden berpendapat bahwa kader posyandu belum mengetahui dengan baik tugas dan tanggungjawabnya sebagai kader. Sementara pada Indikator kinerja Timeli, 5 orang responden menyatakan bahwa ketepatan waktu pemberian pelayanan masih kurang, sehingga membuat para ibu, lama menunggu giliran. Bahkan 2 diantaranya menyatakan bahwa, kader posyandu tidak selalu mendahulukan mereka yang datang lebih dahulu.

Pada variabel kepuasan, berdasarkan 5 indikator kepuasan, hampir sebagian besar diantaranya tidak puas dan bervariasi sesuai indikator kepuasan dengan pelayanan kader. Pada indikator Daya Tanggap, dimana 3 responden menyatakan bahwa kader tidak memberikan penjelasan secara lugas mengenai pelayanan yang diberikan. Pada indikator Kehandalan, 2 orang responden menyatakan kader selalu tidak tepat waktu dalam membuka pelayanan posyandu. 4 orang responden menyatakan pelayanan posyandu lama sehingga tidak sesuai harapan, pada indikator Assurance, 2 diantaranya menyatakan kader posyandu kurang memberikan jaminan keamanan dan kenyamanan ketika pelayanan posyandu berlangsung. Pada indikator empati, 2 responden berpendapat bahwa kader kurang rama, dan kurang respek terhadap balita yang menangis. Sementara pada indikator bukti fisik, hanya ada 1 orang yang berpendapat bahwa lingkungan posyandu kurang bersih.

Berdasarkan latar belakang diatas maka peneliti tertarik melakukan penelitian dengan judul Hubungan Kinerja Kader Posyandu Dengan Kepuasan Pelayanan Posyandu Balita di RW 012 Kelurahan Kapuk Tahun 2020. Tujuan umum penelitian ini adalah Untuk Mengetahui hubungan antara kinerja kader Posyandu terhadap kepuasan Pelayanan Posyandu Balita di RW 012 Kelurahan Kapuk Tahun 2020.

\section{METODE PENELITIAN}

Jenis penelitian yang digunakan adalah Analitik kuantitatif dengan menggunakan pendekatan studi Cross Sectional, yaitu suatu studi yang meneliti variable terikat dan variable bebas dalam suatu waktu yang sama. Sampel yang digunakan dalam penelitian ini berjumlah 319 Ibu pengguna Posyandu Balita. Teknik pengumpulan data dilakukan dengan cara menyebarkan kuesioner langsung dengan ibu pengguna posyandu balita. Data penelitian yang sudah di dapat di analisis dengan menggunakan analisis univariat dan bivariat. 


\section{HASIL PENELITIAN}

Hasil Analisis Univariat

Tabel 1.1

Distribusi Frekuensi Kepuasan Pelayanan Posyandu Balita di RW 012 Kelurahan Kapuk Jakarta Tahun 2020

\begin{tabular}{ccc}
\hline Variabel Kepuasan & Jumlah & Presentase (\%) \\
\hline Kurang Puas & 123 & $38,6 \%$ \\
Puas & 196 & $61,4 \%$ \\
Total & 319 & $100 \%$ \\
\hline
\end{tabular}

Tabel 1.2

Distribusi Frekuensi Kinerja Kader Posyandu Balita di RW 012 Kelurahan Kapuk Jakarta Tahun 2020

\begin{tabular}{ccc}
\hline Variabel Kinerja & Jumlah & Presentase (\%) \\
\hline Kurang Baik & 88 & $27,5 \%$ \\
Baik & 231 & $72,4 \%$ \\
Total & 319 & $100 \%$ \\
\hline
\end{tabular}

\section{Hasil Analisis Bivariat}

Tabel 1.3

Hubungan Antara Kinerja Kader Posyandu Balita Terhadap Kepuasan Pelayanan Posyandu Balita di RW 012 Kelurahan Kapuk Jakarta Tahun 2020

\begin{tabular}{|c|c|c|c|c|c|c|c|c|}
\hline \multirow{3}{*}{ Kinerja } & \multicolumn{4}{|c|}{ Kepuasan } & & & \multirow{3}{*}{ P Value } & \multirow{3}{*}{$\begin{array}{c}\text { OR }(95 \% \\
\quad \mathrm{Cl})\end{array}$} \\
\hline & \multicolumn{2}{|c|}{ Kurang Puas } & \multicolumn{2}{|c|}{ Puas } & \multicolumn{2}{|c|}{ Total } & & \\
\hline & $n$ & $\%$ & $\mathrm{~N}$ & $\%$ & $n$ & $\%$ & & \\
\hline Kurang Baik & 53 & 60,2 & 35 & 39,8 & 88 & 100 & & 3,483 \\
\hline Baik & 70 & 30,3 & 161 & 69,7 & 231 & 100 & 0,0001 & $(2,090-$ \\
\hline Total & 123 & 38,6 & 196 & 61,4 & 319 & 100 & & $5,805)$ \\
\hline
\end{tabular}

Hasil penelitian Hubungan Antara

Kinerja Kader Posyandu Balita Terhadap Kepuasan Pelayanan Posyandu Balita di RW 012 Kelurahan Kapuk Jakarta Tahun 2020, terlihat bahwa dari 319 jumlah total responden, 88 diantaranya menyatakan kinerja kader kurang baik dan 231 responden menyatakan kinerja kader baik. Responden yang menyatakan kinerja kader kurang baik, 60,2 \% diantaranya kurang puas dengan kinerja kader. Sementara responden yang menyatakan kinerja kader baik, $30,3 \%$ diantaranya kurang puas dengan kinerja kader.

Hasil Uji Statsitik Chi-Square diperoleh niliai $P$ Value sebesar 0,0001 . Nilai ini lebih kecil dari Alpha 0,05. Dengan demikian maka ada Hubungan Antara Kinerja Kader Posyandu Balita Dengan Kepuasan Ibu Pengguna Posyandu Balita di Rw 012 Kelurahan Kapuk Jakarta Tahun 2020. Hasil uji pula diperoleh nilai OR sebesar 3,483 dengan $\mathrm{Cl}(2,090-5,805)$, artinya responden yang menyatakan kinerja kader kurang baik memiliki peluang 
3 kali lebih besar untuk kurang puas terhadap kinerja kader dibandingkan dengan responden yang menyatakan kinerja kader baik.

\section{PEMBAHASAN}

Setiap individu atau organisasi tentu memiliki tujuan yang akan dicapai dengan menetapkan target atau sasaran. Keberhasilan individu atau organisasi dalam mencapai target atau sasaran tersebut merupakan kinerja. Seperti yang diungkapkan oleh Prawirosentono (1999) dalam Suwardana, (2014) yang mengartikan kinerja sebagai, hasil kerja yang dapat dicapai oleh seseorang atau kelompok orang dalam suatu organisasi, sesuai dengan wewenang dan tanggung jawab masing-masing [5]. Sementara Kepuasan adalah suatu keadaan dimana keinginan harapan dan kebutuhan individu terpenuhi. Artinya, individu datang ke suatu pelayanan untuk mendapatkan apa yang diinginkan untuk memenuhi kebutuhannya. Menurut Suprapto, (1997) dalam Suwardana, (2014), kepuasan pelanggan berarti bahwa kinerja suatu barang sekurang-kurangnya sama dengan apa yang diharapkan. Nursalam, (2010) dalam Chasana, (2015) juga mengungkapkan bahwa kepuasan adalah perasaan senang seseorang yang berasal dari perbandingan antara kesenangan terhadap aktifitas dari satu produk dan harapannya [6].

Setiap individu atau organisasi tentu memiliki tujuan yang akan dicapai dengan menetapkan target atau sasaran. Keberhasilan individu atau organisasi dalam mencapai target atau sasaran tersebut merupakan kinerja. Seperti yang diungkapkan oleh Prawirosentono (1999) dalam Suwardana, (2014) yang mengartikan kinerja sebagai, hasil kerja yang dapat dicapai oleh seseorang atau kelompok orang dalam suatu organisasi, sesuai dengan wewenang dan tanggung jawab masing-masing. Sementara Kepuasan adalah suatu keadaan dimana keinginan harapan dan kebutuhan individu terpenuhi. Artinya, individu datang ke suatu pelayanan untuk mendapatkan apa yang diinginkan untuk memenuhi kebutuhannya. Menurut Suprapto, (1997) dalam Suwardana, (2014), kepuasan pelanggan berarti bahwa kinerja suatu barang sekurang-kurangnya sama dengan apa yang diharapkan. Nursalam, (2010) dalam Chasana, (2015) juga mengungkapkan bahwa kepuasan adalah perasaan senang seseorang yang berasal dari perbandingan antara kesenangan terhadap aktifitas dari satu produk dan harapannya [7].

Berbagai teori maupun hasil penelitian membuktikan bahwa kepuasan 
pengguna posyandu balita sangat erat hubungannya dengan kinerja kader. Dalam penelitian kali ini, berdasarkan hasil analisis statistik univariat terlihat bahwa sebagian besar responden menyatakan kader posyandu memiliki kinerja baik, yaitu sebesar $72,4 \%$, sementara responden yang menyatakan kinerja kader kurang baik sebesar 27,6\%. Hal ini dimungkinkan karena faktor personal berupa kemampuan dan ketrampilan dari kader itu sendiri, sikap yaitu cara kader dalam memberikan pelayanan apakah ramah, sopan, dan lainlain seperti sistem kerja, fasilitas kerja sehingga kinerja kader dirasakan kurang baik oleh ibu balita. Sementara kepuasan Ibu pada kategori Puasa sebesar 61,4\% dan pada kategori kurang puas sebesar 38,6\%. Hal ini berbanding lurus dengan persepsi responden terhadap kinerja kader tersebut.

Hasil Uji Statsitik Chi-Square diperoleh niliai P Value sebesar 0,0001. Nilai ini lebih kecil dari alpha 0,05. Dengan demikian maka ada Hubungan Antara Kinerja Kader Posyandu Balita Dengan Kepuasan Ibu Pengguna Posyandu Balita di RW 012 Kelurahan Kapuk Jakarta Tahun 2020. Hasil penelitian ini sejalan Chasanah 2015, dimana hasil analisis statistik dan pengujian hipotesis diketahui bahwa ada hubungan antara kinerja kader Posyandu dengan tingkat kepuasan ibu balita di
Dusun Blendangan Kecamatan Berbah Kabupaten Sleman, ditunjukkan oleh nilai signifikansi yang kurang dari 0,05 $(p=0,000<0,05)$. Sejalan juga dengan penelitian Suhriyah 2012 yang menemukan bahwa ada hubungan antara kinerja kader posyandu dengan tingkat kepuasan ibu balita di Posyandu Desa Ngampel Kecamatan Kapas Kabupaten Bojonegoro tahun 2011 [8].

Danan 2007 berpendapat bahwa, Kepuasan merupakan fungsi dari perbedaan antara kinerja yang dirasakan dengan harapan. Ibu akan merasa puas apabila kinerja layanan kesehatan yang diperolehnya sama atau melebihi harapannya dan sebaliknya. Ketidakpuasan atau perasaan kecewa akan muncul apabila kinerja layanan kesehatan yang diperolehnya itu tidak sesuai dengan harapannya. Ibu merasa puas apabila harapannya terpenuhi atau akan sangat puas jika harapan terlampaui. Penampilan atau hasil kerja para kader dalam memberikan pelayanan yang merupakan perpanjangan tangan pelayanan tenaga kesehatan harus selalu aktif, dibuktikan dengan kinerja yang baik. Kinerja kader yang baik secara kualitas dan kuantitas harus selalu ditingkatkan. Hal itu menunjukan besarnya peran serta masyarakat dan besarnya tingkat 
kepedulian masyarakat terhadap kesehatan khususnya kesehatan balita.

Peneliti kemudian berpendapat bahwa ada hubungan antara kinerja kader dengan kepusan ibu balita ini disebabkan karena ketidaksesuaian antara harapan dan kenyataan yang di alami oleh ibu pada waktu mengikuti posyandu balita. Hal ini menyebabkan persepsi ibu terhadapa layanan kinerja selama proses menikmati jasa pelayanan posyandu balita dirasa tidak memuaskan. Dengan demikian maka rekomendasi yang bisa peneliti sampaikan adalah, perlu ditingkatkan lagi kinerja kader dalam memberikan pelayanan kepada ibu pengguna posyandu terutama harus bisa menumbuhkan daya tanggap, mampu memberikan jaminan keamanan dan kenyamanan kepada pelanggan, serta bersedia mendengarkan keluhan-keluhan pelanggan, memberikan penjelasan pelayanan secara ramah. Hal ini akan menumbuhkan rasa puas pada pengguna jasa dalam hal ini ibu pengguna posyandu balita akan pelayanan posyandu yang diberikan.

\section{SIMPULAN}

Berdasarkan hasil penelitian dan pembahasan pada bab sebelumnya tentang Hubungan Kinerja Kader Posyandu Dengan Kepuasan Pelayanan Posyandu Balita di RW 012 Kelurahan Kapuk Tahun
2020 maka dapat disimpulkan sebagai berikut :

1. Berdasarkan hasil penelitian didapatkan bahwa pada variabel kepuasan, presentase terbanyak adalah pada responden yang menyatakan puas yaitu $61,4 \%$ dibandingkan dengan responden yang kurang puas yaitu sebanyak $38,6 \%$.

2. Pada variabel Kinerja, presentase terbanyak adalah pada responden yang menyatakan kinerja kader baik yaitu $72,4 \%$ dibandingkan dengan responden yang menyatakan kinerja kader kuran yaitu sebanyak 27,6\%.

3. Hasil uji statistik diperoleh ada Hubungan Antara Kinerja Kader Posyandu Balita Terhadap Kepuasan Ibu Pengguna Posyandu Balita di RW 012 Kelurahan Kapuk Jakarta Tahun 2020 ( nilai $p=0,0001$ dan OR: 3,483 dengan $\mathrm{Cl}: 2,090-5,805)$.

\section{DAFTAR PUSTAKA}

[1]. Kemenkes, R. I. (2018). Petunjuk Teknis Penyelenggaraan Posyandu Remaja .Jakarta: Kemenkes RI.

[2]. Dinkes DKI Jakarta Profil kesehatan 2018, Jakarta : Dinas Kesehatan Provinsi DKI Jakarta.

[3]. Pertiwi, A. (2017). Analisis perbedaan kualitas pelayanan pada pasien bpjs 
dan pasien umum terhadap kepuasan pasien di rawat jalan rsud kota surakarta. Jurnal Manajemen Dayasaing, 18(2), 113-121.

[4]. Trisnawati, Komang. 2015. Analisis kepuasan pasien rawat jalan Pns Pada Masa Pelaksanaan Askes Dan Jkn Di Rsup Dr.sardjito Yogyakarta. Tesis, Universitas Gajah Mada, Yogyakarta, Indonesia.

[5]. Suwardana, Dewa Made. 2014. Hubungan Kinerja Petugas Dengan Kepuasan Ibu Pengguna Posyandu Di Wilayah Kerja Puskesmas Lombakasi Kecamatan Lantari Jaya Tahun 2014. Artikel Academi Edu, https://www.academia.edu/10946406/ hubungan_kinerja_petugas_dengan_ke puasan_ibu_pengguna_posyandu_di_ wilayah_kerja_puskesmas_lombakasi_ kecamatan_lantari_jaya_tahun_2014. (Diakses, 31/8/2020).
[6]. Chasanah, S. U. (2015) Hubungan Kinerja Kader Posyandu Dengan Tingkat Kepuasan Ibu Balita Dalam Pelayanan Posyandu. Jurnal Akbiduk

[7]. Tjiptono, F. dan Chandra. 2011. Service, Quality, and Satisfaction, 3rd ed. Yogyakarta

[8]. Danan, M. H. (2007). Hubungan Kepuasan Kerja dan Komitmen Organisasi dengan Organizational Citizenship Behavior (OBC) dalam http://www.ejournal.unesa.ac.id. Diakses pada tanggal 18 Agustus 2020 